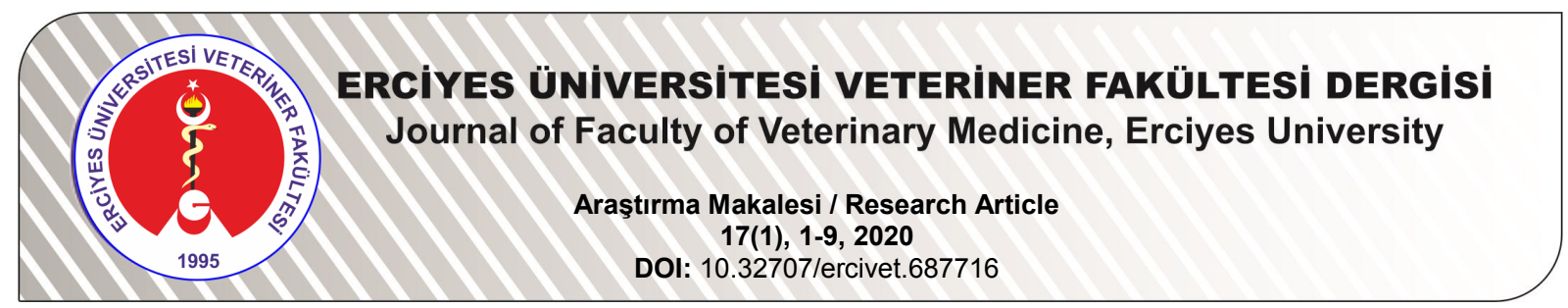

\title{
Konya İli Kadınhanı ve Sarayönü İlçelerinde İthal ve Yurt İçinden Temin Edilen Hayvanlarla Sığır Besiciliği Yapan İşletmelerin Ekonomik Analizi*
}

\author{
Ömer GEZGINÇ ${ }^{1}$, Aytekin GÜNLÜ ${ }^{2}$ \\ ${ }^{1}$ Tarım ve Kırsal Kalkınmayı Destekleme Kurumu, Van İl Koordinatörlüğü, Van-TÜRKIYE \\ ${ }^{2}$ Selçuk Üniversitesi Veteriner Fakültesi, Hayvancılık Ekonomisi ve İşletmeciliği ABD, Konya- TÜRKIYE
}

Sorumlu yazar: Aytekin GÜNLÜ, E-posta: agunlu@selcuk.edu.tr; ORCID: 0000-0002-1989-8119

Atıf yapmak için: Gezginç Ö, Günlü A. Konya ili Kadınhanı ve Sarayönü ilçelerinde ithal ve yurt içinden temin edilen hayvanlarla sığır besiciliği yapan işletmelerin ekonomik analizi. Erciyes Üniv Vet Fak Derg 2020; 17(1):1-9.

Özet: Bu çalışmada, Konya iline bağlı Kadınhanı ve Sarayönü ilçelerinde canlı hayvan materyalini yurt içinden ve ithalat yoluyla temin ederek sığır besiciliği yapan işletmelerin teknik, ekonomik ve yapısal özellikleri karşılaştırılmıştır. Besi materyalini yurt içinden temin eden 58 işletme (I. grup), ithal olarak temin eden 10 adet işletme (II. grup); toplamda 68 adet işletme ile anket yapılarak ekonomik analiz için gerekli veriler elde edilmiştir. İncelenen işletmeler için; masraf unsurları olan besi materyali, yem, işçilik, veteriner-sağılı giderleri, amortismanlar, bakım-onarım masrafları, genel idare giderleri ve diğer giderlerin toplam giderler içindeki oransal dağılımı sırasıyla işletmeler genelinde $\% 49.22, \%$ 32.98, \%8.67, \%1.40, \%1.09, \%1.44, \%2.91, \%2.29; I. grup işletmelerde \%48.83, \%32.81, \%9.16, \%1.45, \%1.09, \% 1.44, \% 2.91, \%2.30; II. grup işletmelerde ise \%51.48, \%33.98, \%5.83, \%1.08, \%1.07, \%1.45, \%2.91, \%2.20 olarak bulunmuştur. İncelenen besi işletmelerinin bir kg karkas maliyeti, bir kg CA artışı maliyeti ve bir kg CA maliyeti sırasıyla işletmeler genelinde 24.20 TL, 10.59 TL, 13.03 TL ve I. grup işletmelerde 24.39 TL, 10.50 TL, 12.98 TL ve II. grup işletmelerde 23.06 TL, 11.08 TL, 13.36 TL olarak bulunmuştur. Çalışma sonucunda ithal ve yurt içinden temin edilen hayvanlarla yapılan beside bir kg karkas maliyeti ve bir kg canlı ağırlık maliyetleri bakımından gruplar arasında farklılık tespit edilememiştir $(P>0.05)$. Sonuç olarak, ithal ve yerli orjinli hayvanlarla yapılan beside birim maliyet açısından bir farkılık olmadığı belirlenmiştir.

Anahtar kelimeler: Ekonomik analiz, sığır besiciliği, üretim masrafları

\section{Economic Analysis of Cattle Fattening Enterprises with Imported and Providing Domestic Animals in} Kadınhanı and Sarayönü District of Konya Province

Summary: In this study, the technical, economic and structural characteristics of fattening live material from the domestic market and importing enterprises in Kadınhanı and Sarayönü districts affiliated to the province of Konya were compared. For this aim, 58 enterprises (Group I), who supplied the fattening material from the domestic market and 10 enterprises (Group II) that supplied them as imports; A total of 68 enterprises were surveyed and necessary data were obtained. In addition, evaluations were made on the whole enterprises basis. For the enterprises examined; fattening material, feed, labor, veterinary-health expenses, depreciation, maintenance and repair expenses,general administrative expenses, other expenses proportional distribution in total expenses were found respectively, $49.22 \%, 32.98 \%$, $8.67 \%, 1.40 \%, 1.09 \%, 1.44 \%, 2.91 \%, 2.29 \%$ for all enterprises; $48.83 \%, 32.81 \%, 9.16 \%, 1.45 \%, 1.09 \%, 1.44 \%$, $2.91 \%, 2.30 \%$ in group I enterprises and $51.48 \%, 33.98 \%, 5.83 \%, 1.08 \%, 1.07 \%, 1.45 \%, 2.91 \%, 2.20 \%$ in group II enterprises. One $\mathrm{kg}$ carcass cost, one $\mathrm{kg}$ live weight increase cost, one $\mathrm{kg}$ live weight cost in the enterprises were found as; 24.20 TL, 10.59 TL, 13.03 TL in all enterprises; 24.39 TL, 10.50 TL, 12.98 TL in group I enterprises and 23.06 TL 11.08 TL, 13.36 TL in group II enterprises, respectively. As a result of the study, it was found that there was no statistically significant difference between the groups in terms of one $\mathrm{kg}$ carcass cost and one $\mathrm{kg}$ live weight costs $(p>0.05)$. In conclusion, it is determined that there is no difference in terms of unit cost in animal fattening activities with imported and domestic origin animals.

Key words: Cattle fattening, economic analysis, production costs

\section{Giriş}

Besicilik, kasaplık hayvanlarda et kalitesinin, et ve yağ miktarının artırımasının yanında, endüstri kalıntılarının ve çeşitli hayvan yemlerinin daha iyi bir biçimde değerlendirilmesine olanak sağlayan ve aynı za-

Geliş Tarihi/Submission Date : 19.01.2019

Kabul Tarihi/Accepted Date : 30.07 .2019

*Çalışma 1 Nolu yazarın yüksek lisans tezinden üretilmiş ve 11-14 Ekim 2018 tarihinde Antalya'da düzenlenen Üçüncü Ulusal Hayvancllık Ekonomisi Kongresi'nde sunulmuştur. manda ekonomiye yeni istihdam sağlayarak katkıda bulunan bir işletme kolu olarak tanımlanmaktadır (Sakarya ve Günlü, 1996).

Kırmızı et içerdiği esansiyel aminoasitler yönüyle insanların beslenmesinde önemli bir yer tutmaktadır. Dünyada nüfus ve gelir düzeyinde yaşanan artış, hayat standartlarının yükselmesi, tüketicilerin beslenme konusunda bilinçlenmeleri sonucunda hayvansal proteinlere olan talep artmaktadır. Ülkeler bu talebi 
karşılamak için hayvansal ürünlerde üretim ve verimliliğin artırıması, fiyat ve pazar mekanizmasını geliştirici, hayvansal üretim-sanayi entegrasyonuna yönelik yapısal reformlar gibi farklı politika ve stratejiler geliştirmektedir (GTHB HAYGEM, 2015).

Türkiye'de de artan nüfusun meydana getirdiği talep artışı ile yükselen sosyo-ekonomik refah düzeyi et üretiminin artırılmasını zorunlu kılmaktadır. Ancak, ülkemizde özellikle son yıllarda kırmızı et üretiminin yetersizliği söz konusudur. Bu kırmızı et açığı bazı dönemlerde kasaplık hayvan ve et ithalatı ile kapatılmaya çalışılmıştır. Kasaplık hayvan ve et ithalatı kısa süreli olarak üretim açığını kapatmakta ancak devamında sektörden, üretimden vazgeçmelere sebep olmakta; uzun dönemde üretim açığının artarak devam etmesine neden olmaktadır. Başka bir ifadeyle; ithalat kısa dönem et açığının kapatılmasının çözümünde etkili gibi olsa da orta ve uzun vadede sektörde olumsuz sonuçlara neden olmaktadır (Aydın ve ark., 2011a; Aydın ve ark., 2011b; Sakarya ve Aydın 2011).

Konuyla ilgili yapılan çalışmalar incelendiğinde, İmik ve ark. (2000), sığır besiciliğinin ekonomisi üzerine Afyon ilinde yaptıkları çalışmada, maliyet unsurlarının giderler içerisindeki paylarını; besilik hayvan maliyeti $\% 51.13$, yem maliyeti $\% 24.80$, işçilik $\% 6.72$, veteriner -sağlık harcamaları \%3.05, amortisman ve bakım onarım masrafları $\% 1.13$, stopaj giderleri $\% 2.03$, genel idare giderleri \%1.02 ve diğer masraflar ise \%9.85 olarak tespit etmişlerdir. Afyon ilinde sığır besiciliği üzerine yapılan başka bir çalışmada, girdi unsurlarının toplam giderler içerisindeki payları şu şekildedir: besilik materyal $\% 53.60$, yem giderleri $\% 29.95$, işçilik giderleri \%6.25, veteriner-sağlık harcamaları \%2.27, amortisman ve bakım-onarım \%1.28, diğer giderler ise \%6.47'dir (Çiçek, 2002). Aydın ve Sakarya (2012), Kars ve Erzurum illerinde entansif sığır besiciliği yapan işletmelerin ekonomik analizlerinin yapılması amacıyla yürüttükleri çalışmada işletmeler genelinde masraflar genel toplamı içerisinde besilik materyalin oranı $\% 50.56$, yem giderinin oranı $\%$ 27.33 , işçiliğin oranı \%11.08, veteriner-sağlık giderlerinin oranı $\% 1.23$, bakım-onarım gideri $\% 1.24$, diğer giderler ise \%6.07 olarak bildirilmiştir. Can (2015), yaptığı çalışmada besi materyali maliyeti, yem maliyetleri, işçilik giderleri, veteriner sağlık giderleri, pazarlama giderleri, amortismanlar, bakım-onarım giderleri ve diğer giderlerin toplam maliyet-ler içindeki paylarını sırasıyla $\% 62.87, \% 23.53, \% 4.58, \% 1.80, \%$ $1.39, \% 1.09, \% 0.83$ ve $\% 3.91$ olarak bulmuştur.

Bu çalışmada Konya ili Kadınhanı ve Sarayönü ilçelerinde ithalat yolu ile besi materyali temin eden işletmeler ile ülkemizdeki mevcut hayvan ırkları ile besicilik yapan işletmelerin karlılığının karşılaştırılması yapılmış, bu işletmelerin teknik ve ekonomik değerlendirilmeleri yapılarak ithal ve Türkiye orjinli hayvanlarla besi faaliyetlerinin sonuçları ortaya konulmaya çalışı- mıştır. İthal edilen besilik hayvanların Türkiye koşullarındaki besi performansları ve ithalatın besicilik sektöründeki işletmelerin karlıı̆ı̆ına olan etkileri incelenmiştir.

\section{Gereç ve Yöntem}

Araştırmanın materyalini, Konya ili Kadınhanı ve Sarayönü ilçeleri ve bu ilçelere bağlı köylerde sığır besiciliği yapan işletmelerden yüz yüze uygulanan anket yoluyla sağlanan veriler oluşturmuştur. İkincil veri olarak araştırma bölgesinde kamu kurum/ kuruluşlarının bilgilerinden ve konu hakkında daha önce yapılan çalışmalarda elde edilen literatür bilgilerinden yararlanılmıştır. Araştırmanın verilerini oluşturan anketler 2017 yılı Ekim-Aralık aylarında uygulanmış ve 2016-2017 üretim periyodu verileri esas alınmıştır.

Örneğe dahil edilecek işletmelerin belirlenmesinde tabakalı örnekleme yöntemi kullanılmıştır. Tabakalı örnekleme yöntemi için yapılan güç analizleri sonucu, gerekli örneklem genişliği seçilecek işletme sayısı için en az 58 işletme olarak belirlenmiştir (Esfahani ve Dougherty, 2018). Bu çalışmada besi materyalini ithal olarak temin eden işletmelerin sayısı 10, ülkemizdeki mevcut hayvan ırkları ile besicilik yapan işlemelerin sayısı 58 olmak üzere toplam 68 adet işletmeye anket uygulanmıştır.

İstatistik analizlerde SPSS 22 (SPSS Statistics for Windows, Version 22.0) programı kullanılmıştır. Veri analizi yapılırken iki grup arasındaki farklılıkları değerlendirmek amacıyla parametrik test ön şartlarının sağlandığı durumda "Student's t Test"; sağlanmadığında ise "Mann Whitney-U testi" kullanılmıştır. Verilerin değerlendirilmesi sonucunda işletmelerin teknik, ekonomik ve rantabilite rasyolarına ilişkin hesaplamalar yapılmıştır. Ancak sınırlı sayıda işletme (2 ya da 3 adet işletme) yabancı sermaye kullandığı için ekonomik rantabilite hesabı yapılmamıştır. Teknik, ekonomik ve rantabilite rasyolarına iliş̧kin hesaplamalar için Çiçek (2002) ve Aydın (2011)'nın bildirdikleri ekonomik analiz yöntemi kullanılmıştır.

\section{Bulgular}

İşletmeler, beside kullanılan materyali yerli pazardan (Türkiye menşeili) ve ithal olarak temin etme durumlarına göre iki grup olarak değerlendirilmiştir. Araştırma kapsamındaki işletmelere ait teknik bulgular Tablo 1, ekonomik değerlendirme sonuçları Tablo 2, Tablo 3, Tablo 4, ve Tablo 5 olarak, sosyo-ekonomik bulgular ise Tablo 6'da verilmiştir.

İncelenen dönemde I. grup işletmelerde 3412 baş sığır, II. grup işletmelerde 2073 baş sığır ve toplamda ise 5485 baş sığır besiye alınmıştır. İşletme başına düşen ortalama hayvan sayıları I. grup işletmeler için 58.82 adet, II. grup işletmeler için 207.3 adet, tüm işletmeler için 80.66 adettir. İşletmeler genelinde top- 
Tablo 1. İncelenen işletmelere ait teknik bulgular

\begin{tabular}{|c|c|c|c|}
\hline Besi İşletmelerinin Bazı Teknik Verileri & $\begin{array}{l}\text { I. Grup } \\
X_{ \pm} S_{\bar{x}}\end{array}$ & $\begin{array}{l}\text { II. Grup } \\
\mathrm{X}_{ \pm} \mathrm{S}_{\overline{\mathrm{X}}}\end{array}$ & $\begin{array}{c}\text { Ortalama } \\
\mathrm{X}_{ \pm} \mathrm{S}_{\overline{\mathrm{X}}} \\
\end{array}$ \\
\hline İşletme Sayısı (adet) & 58 & 10 & 68 \\
\hline Toplam Kurulu Kapasite (baş) & 9410 & 5990 & 15400 \\
\hline Besiye Alınan Toplam Hayvan Sayısı (baş) & 3412 & 2073 & 5485 \\
\hline Kapasite Kullanım Oranı (\%) & 36.26 & 34.60 & 35.62 \\
\hline Besi Süresi (gün) & $302.93 \pm 7.34$ & $304.50 \pm 13.77$ & $303.16 \pm 6.54$ \\
\hline Besi Başı Canlı Ağırlık (kg/baş) & $245 \pm 5.56$ & $284.40 \pm 7.01$ & $250.79 \pm 5.13$ \\
\hline Besi Sonu Canlı Ağılık (kg/baş) & $616.47 \pm 7.68$ & $694.50 \pm 29.27$ & $627.94 \pm 8.43$ \\
\hline Canlı Ağırık Artışı (kg/baş) & $371.47 \pm 8.25$ & $410.10 \pm 32.07$ & $377.15 \pm 8.51$ \\
\hline Günlük CAA (g) & $1226 \pm 0.02$ & $1340 \pm 0.07$ & $1250 \pm 0.02$ \\
\hline $\begin{array}{l}1 \text { kg CAA İçin Tüketilen Kuru Madde Cinsinden } \\
\text { Yem Miktarı (kg) }\end{array}$ & $10 \pm 0.41$ & $11.91 \pm 1.25$ & $10.28 \pm 0.40$ \\
\hline Sıcak Karkas Ağırlığı (kg/baş) & $326.97 \pm 3.90$ & $400.60 \pm 14.48$ & $337.79 \pm 5.03$ \\
\hline Karkas Randımanı (\%) & $53.17 \pm 0.45$ & $56.86 \pm 1.68$ & $53.71 \pm 0.48$ \\
\hline
\end{tabular}

I. grup: Yerli orjinli hayvan kullanan işletmeler; II. grup: Ithal orjinli hayvan kullanan işletmeler

lam kurulu kapasite 15400 , I. grup işletmelerde 9 410, II. grup işletmelerde 5990 baştır. Kapasite kullanım oranının I. grup işletmelerde \%36.26, II. grup işletmelerde \%34.60, toplamda ise \%35.62 olduğu tespit edilmiştir.

İncelenen işletmeler için; masraf unsurları olan besi materyali, yem, işçilik, veteriner-sağlık giderleri, amortismanlar, bakım-onarım masrafları, genel idare giderleri, diğer giderlerin toplam giderler içindeki oransal dağılımı sırasıyla işletmeler genelinde \% 49.22, \%32.98, \%8.67, \%1.40, \%1.09, \%1.44, \%2.91, $\% 2.29$; I. grup işletmelerde $\% 48.83, \% 32.81, \% 9.16$, $\% 1.45, \% 1.09, \% 1.44, \% 2.91, \% 2.30$; II. grup işletmelerde ise $\% 51.48, \% 33.98, \% 5.83, \% 1.08, \% 1.07$, $\% 1.45, \% 2.91, \% 2.20$ olarak bulunmuştur.

İncelenen işletmeler için besi sonu maliyetleri olarak bir kg karkas maliyeti, bir kg CA artışı maliyeti ve bir kg CA maliyeti hesaplanmıştır. Bir kg CA artışı maliyeti ve bir kg CA maliyeti sırasıyla işletmeler genelinde 24.20TL (7.75\$), 10.59TL (3.40\$), 13.03TL (4.18 $\$) ;$ I. grup işletmelerde 24.39TL (7.82\$), 10.50TL (3.37\$), 12.98TL (4.16\$) ve II. grup işletmelerde 23.06TL (7.40\$), 11.08TL (3.55\$), 13.36TL (4.28\$) olarak bulunmuştur.

İşletmelerin gruplar itibariyle besi materyalini ithal veya yerli orjinli hayvan tercih etmesinin bir kg karkas maliyeti ve bir kg canlı ağılık maliyetleri bakımından $p<0.05$ şartı sağlanamadığı için gruplar arasında anlamlı bir farklılık olmadığı anlaşılmıştır.

İşletmelerin net kar/zarar durumları her iki grup için de pozitif çıkmıştır. I. grup işletmelere ait net/kar zarar durumu işletmeler genel ortalamasının altında

Tablo 2. Girdi unsurlarının masraflar genel toplamı içindeki payları (\%)

\begin{tabular}{lccc}
\hline Girdi Unsurları & I. Grup & II. Grup & Genel \\
\hline Besi Materyali Maliyeti & 48.83 & 51.48 & 49.22 \\
Yem Giderleri & 32.81 & 33.98 & 32.98 \\
İşilik Giderleri & 9.16 & 5.83 & 8.67 \\
Veteriner Sağlık Giderleri & 1.45 & 1.08 & 1.4 \\
Amortismanlar & 1.09 & 1.07 & 1.09 \\
Bakım - Onarım Giderleri & 1.44 & 1.45 & 1.44 \\
Genel İdare Giderleri & 2.91 & 2.91 & 2.91 \\
Diğer Giderler & 2.3 & 2.2 & 2.29 \\
\hline
\end{tabular}

I. grup: Yerli orjinli hayvan kullanan işletmeler; II. grup: Ithal orjinli hayvan kullanan işletmeler 
iken II. grup işletmelerde ise işletmeler genel ortalamasının üstünde olduğu bulunmuştur. II. grup işletmelerin daha karlı olduğu tespit edilmiştir. eğilimindedir. Üreticiler bunun sebebi olarak besilik hayvan materyali ve yem maliyetlerinin yüksek olduğunu bildirmişlerdir.

Tablo 3. İncelenen besi işletmelerinin besi sonu maliyet değerleri

\begin{tabular}{|c|c|c|c|c|c|}
\hline Bazı İşletme Sonu Değerleri & $\begin{array}{l}\text { I. Grup } \\
X_{ \pm} S_{\bar{X}}\end{array}$ & $\begin{array}{l}\text { II. Grup } \\
X_{ \pm} S_{\bar{X}}\end{array}$ & $\begin{array}{l}\text { Genel } \\
{ }_{X \pm} S_{\bar{X}}\end{array}$ & Min/Maks. & $\mathbf{P}$ \\
\hline İşletme Sayısı (N) & 58 & 10 & 68 & & \\
\hline Bir kg Karkas Maliyeti (TL) & $24.39 \pm 2.93$ & $23.06 \pm 2.85$ & $24.20 \pm 2.93$ & $19.45 / 35.11$ & 0.121 \\
\hline Bir kg CA Artışı Maliyeti (TL) & $10.50 \pm 2.49$ & $11.08 \pm 3.70$ & $10.59 \pm 2.68$ & $7.72 / 21.70$ & \\
\hline Bir kg CA Maliyeti (TL) & $12.98 \pm 1.85$ & $13.36 \pm 2.00$ & $13.03 \pm 1.86$ & $10.19 / 19.79$ & \\
\hline
\end{tabular}

I. grup: Yerli orjinli hayvan kullanan işletmeler; II. grup: Ithal orjinli hayvan kullanan işletmeler

Yapılan rantabilite faktörü değerlendirmesine göre; her 100 TL'lik gayri safi hasılanın I. grup işletmeler için 3.86'sı, II. grup işletmeler için 5.13'ü ve işletmeler genelinde ise 4.04'ü saf hasıla olarak çıkmıştır. İncelenen dönemde cari faiz oranı 4.73 olduğu tespit edilmiştir.

İşletme sahiplerinin \%14.7'si sığır besiciliği ile ilgili seminer gibi eğitim faaliyetlerine katılmışlardır. I.
Yapılan çalışmada besi sistemi olarak daha çok açık serbest dolaşımlı besi sistemi $(\% 79,31)$ tercih edilmiştir. Bu sistem; hayvanların bakım, besleme ve idaresi kolay olması nedeniyle daha çok tercih edilmiştir. Bunun dışında besi performansının daha iyi olması ve diğer sistemlere göre daha karlı olmasının da açık serbest dolaşımlı besi sisteminin tercih edilmesinde etkili olduğu tespit edilmiştir.

Tablo 4. İşletmelerin hayvan başına toplam gelir, toplam maliyet ve net kar/zarar değerleri

\begin{tabular}{|c|c|c|c|c|}
\hline Parametreler & $\begin{array}{l}\text { I. Grup } \\
X_{ \pm} S_{\bar{X}} \\
\end{array}$ & $\begin{array}{l}\text { II. Grup } \\
X_{ \pm} S_{\bar{x}}\end{array}$ & Min/Maks. & $\begin{array}{l}\text { Genel } \\
X_{ \pm}{ }^{S_{\bar{X}}}\end{array}$ \\
\hline İşletme Sayısı (N) & 58 & 10 & & 68 \\
\hline Toplam Gelir (TL/Baş) & $7250.35 \pm 131.44$ & $9357.04 \pm 535.75$ & $\begin{array}{l}5833.67 / \\
11798.96\end{array}$ & $7560.16 \pm 162.84$ \\
\hline Toplam Maliyet (TL/Baş) & $6938.97 \pm 111.44$ & $8820.52 \pm 455.63$ & $\begin{array}{l}5804.55 / \\
11708.81\end{array}$ & $7215.67 \pm 140.50$ \\
\hline Net Kar/Zarar (TL/Baş) & $311.38 \pm 73.58$ & $536.52 \pm 278.10$ & $\begin{array}{l}-779.35 / \\
2809.82\end{array}$ & $344.49 \pm 74.57$ \\
\hline
\end{tabular}

I. grup: Yerli Orjinli Hayvan Kullanan Işletmeler; II. grup: Ithal Orjinli Hayvan Kullanan Işletmeler

grupta iki veteriner hekim, II. grupta ise bir veteriner hekim hekimliğin yanında sığır besiciliği de yapmaktadır.

İşletme sahiplerinin \%41.18'i sığır besiciliğini bırakma
İşletme sahiplerinin \%86.76'sı yılda bir defa, \% 10.29 'u yılda iki defa, \%2.94'ü yılda üç defa besi faaliyeti sürdürmektedir. Bu durum araştırma bölgesinde sığır besi faaliyetlerinin belirli dönemlerde yoğunlaşa-

Tablo 5. İşletmelere ait rantabilite rasyoları ve çıktı/girdi oranı

\begin{tabular}{|c|c|c|c|}
\hline Rantabilite Rasyoları & $\begin{array}{l}\text { I. Grup } \\
X_{ \pm} S_{\bar{X}}\end{array}$ & $\begin{array}{l}\text { Il. Grup } \\
X_{ \pm} S_{\bar{X}} \\
\end{array}$ & $\begin{array}{r}\text { Genel } \\
\mathrm{X}_{ \pm} \mathrm{S}_{\overline{\mathrm{X}}} \\
\end{array}$ \\
\hline Mali Rantabilite (\%) & $4.58 \pm 0.83$ & $5.67 \pm 1.95$ & $4.74 \pm 0.76$ \\
\hline Rantabilite Faktörü (\%) & $3.86 \pm 0.87$ & $5.13 \pm 2.41$ & $4.04 \pm 0.82$ \\
\hline Çıktı/Girdi Oranı & $1.07 \pm 0.01$ & $1.03 \pm 0.03$ & $1.05 \pm 0.11$ \\
\hline
\end{tabular}

I. grup: Yerli orjinli hayvan kullanan işletmeler; II. grup: Ithal orjinli hayvan kullanan işletmeler 
Tablo 6. Kadınhanı ve Sarayönü ilçeleri sığır besi işletme sahiplerine ait bazı sosyo-ekonomik özellikleri

\begin{tabular}{|c|c|c|c|c|c|c|c|}
\hline \multirow[t]{2}{*}{ Özellik } & \multirow[t]{2}{*}{ İlçelerde Dağılım } & \multicolumn{2}{|c|}{ I. Grup } & \multicolumn{2}{|c|}{ II. Grup } & \multicolumn{2}{|c|}{ Genel } \\
\hline & & Sayı & $(\%)$ & Sayı & (\%) & Sayı & $(\%)$ \\
\hline \multirow{2}{*}{$\begin{array}{l}\text { Sığır Besiciliği } \\
\text { İle İlgili Eğitim } \\
\text { Durumu }\end{array}$} & Evet & 7 & 12 & 3 & 30 & 10 & 14.70 \\
\hline & Hayır & 51 & 88 & 7 & 70 & 58 & 85.30 \\
\hline \multirow{3}{*}{$\begin{array}{c}\text { Sığır } \\
\text { Besiciliği } \\
\text { Yapma } \\
\text { Nedeni }\end{array}$} & Karlı Olduğu İçin & 9 & 15.52 & 4 & 40 & 13 & 19.12 \\
\hline & Ek İş & 25 & 43.10 & 4 & 40 & 29 & 42.65 \\
\hline & Başka İş Seçeneği Olmadığı İçin & 24 & 41.38 & 2 & 20 & 26 & 38.23 \\
\hline \multirow{2}{*}{$\begin{array}{l}\text { Besiciliği Sür- } \\
\text { dürme Eğilimi }\end{array}$} & Bırakmayı Düşünüyor & 26 & 44.83 & 2 & 20 & 28 & 41.18 \\
\hline & Bırakmayı Düşünmüyor & 32 & 55.17 & 8 & 80 & 40 & 58.82 \\
\hline \multirow{4}{*}{$\begin{array}{c}\text { Tercih } \\
\text { Edilen Besi } \\
\text { Sistemi }\end{array}$} & Açık Serbest Dolaşımlı & 46 & 79.31 & 6 & 60 & 52 & 76.47 \\
\hline & Açık Bağlı & 0 & 0 & 0 & 0 & 0 & 0 \\
\hline & Kapalı Serbest Dolaşımlı & 2 & 3.45 & 3 & 30 & 5 & 7.35 \\
\hline & Kapalı Bağlı & 10 & 17.24 & 1 & 10 & 11 & 16.18 \\
\hline Yılda Yapılan & 1 & 54 & 93.10 & 5 & 50 & 59 & 86.76 \\
\hline Besi & 2 & 3 & 5.17 & 4 & 40 & 7 & 10.29 \\
\hline Sayısı & 3 & 1 & 1.73 & 1 & 10 & 2 & 2.94 \\
\hline
\end{tabular}

I. grup: Yerli orjinli hayvan kullanan işletmeler; II. grup: Ithal orjinli hayvan kullanan işletmeler

rak arzın da bir dönemde artmasına ve yıl genelinde arz-talep dengesinin istenildiği şekilde sağlanamamasına neden olmaktadır. Bu şekilde işleyen bir piyasa yapısında önemli fiyat dalgalanmaları meydana gelmekte ve üreticilerin dezavantajına durumlar yaşanabilmektedir.

\section{Tartışma ve Sonuç}

Araştırma kapsamında yer alan işletmelerin çoğunluğunda sığır besiciliği, bazı tarımsal ve diğer hayvancılık faaliyetleriyle birlikte yürütülmektedir. Bu durum özellikle I. grup işletmelerde daha yoğun görülmektedir. II. grup işletmelerin büyük bir kısmında birincil iş olarak sığır besiciliği yapılmaktadır. I. grup işletmelerin çoğunluğu aile işletmesi konumundadır. Ancak II. grup işletmelerde ise daha modern ve daha bilinçli bir sığır besiciliği faaliyeti yürütülmektedir. II. grup işletmeler günümüzde makineleşmenin artmasıyla silo yem karma ve dağıtma römorku, yem kırma makinesi, genel takip için otomasyon sistemleri, canlı ağırlık artışı takibi için kantar, sağlık yönünden tırnak kesme ve ayak banyoluğu, atık yönetimi için gübre karıştırı$\mathrm{Cl}$, gübre seperatörü gibi makine-ekipmanlara sahip ve işletme kayıtları düzenli tutulan modern işletmelerdir.

Besi süresi işletmeler genelinde ortalama $303.16 \pm 6.54$ gün olarak bulunmuştur. I. ve II. grup işletmelerde bu değerin genel ortalamaya yakın olduğu görülmüştür. Besi süresi günlük canlı ağırlık artışı ve bir kg CAA için tüketilen kuru madde cinsinden yem miktarına etki etmektedir. Nitekim, yapılan bir çalışmada besi süresi uzadıkça; günlük CA artışının düştüğü, bir kg CAA için tüketilen kuru madde cinsinden yem tüketiminin arttığı bildirilmiştir (Özlütürk ve ark., 2008). Besi süresinin uzaması neticesinde gerçekleşen geç kesimlerden dolayı çok büyük kaynak kayıpları da ortaya çıkmaktadır (Topcu, 2004). Besi devam ederken günlük besi giderinin, günlük canlı ağırlık artışı değerine eşit olduğu zaman besiye son verilmelidir (Sakarya ve Günlü, 1996). Tespit edilen besi süresi bazı çalışmalardan (İmik ve ark., 2000; Çiçek, 2002; Hazneci, 2007; Yücel, 2007; Aydın ve Sakarya, 2012; Can, 2015; Çelik ve Sarı̈zkan, 2017 yüksek bulunmuştur. Besi süresi açısından çalışmadaki işletmelerin karlı bir besicilik yapmadıkları söylenebilir.

Sığır besicilik faaliyetinde besi başı canlı ağırlığın işletmenin karlılığı üzerine önemli etkisinin bulunduğunu ve besi başı canlı ağılık azaldıkça; işletme karlılığının artı̆ğı yapılan bir çalışmada belirlenmiştir (Cevger ve ark., 2003). Yapılan incelemede araştırma kapsamındaki işletmelerde besi başı canlı ağırlığın genel ortalaması $250.79 \pm 5.13 \mathrm{~kg}$ olarak bulunmuştur. I. grup işletmeler genel ortalamaya yakın iken II. grup işletmelerde bu değer 284.4 kg'a kadar yükselmiştir. Bulunan bu besi başı canlı ağırlığı değerlerinin çalışmadaki işletmelerin karlılığına olumsuz olarak yansıdığı söylenebilir. Bulunan bu değerler Akbulut ve ark.'ın (1995) yaptığı çalışmadan düşük; yapıIan bazı çalışmalardan (İmik ve ark., 2000; Çiçek, 2002; Altuntaş ve Arpacık, 2004; Aydın ve Sakarya 2012; Can, 2015; Çelik ve Sarıözkan, 2017) ise yüksek çıkmıştır.

İşletmeler genel ortalamasında günlük canlı ağırlık artışı $1250 \pm 0.02 \mathrm{gr}$ olarak tespit edilmiştir. I. grup işletmeler genel ortalamaya yakın iken II. grup işletmelerde bu değer genel ortalamadan yüksektir. Bu durum, I. grup işletmelerde kullanılan rasyon içeriği- 
nin bilinçli bir şekilde hazırlanamamasından kaynaklanabileceği gibi; II. grup işletmelerin beside daha çok kültür ırkları ve melezlerini kullanmasına da bağlanabilir. Tespit edilen ortalama günlük canlı ağırlık artışı yapılan bazı araştırmalardaki (Sakarya ve Günlü, 1996; Hazneci, 2007; Aydın ve Sakarya, 2012; Çelik ve Sarı̈zkan, 2014; Can, 2015; Muižniece ve Kairiša, 2016) değerlerden yüksek bulunmuştur. Elde edilen bu değerler bazı çalışmalar (İmik ve ark., 2000; Çiçek, 2002; Syrůček ve ark., 2017) ile benzer bulunmuştur.

Sığır besiciliğinde, genç olan hayvanların yemden yararlanma oranının daha yüksek olması ve bir kg CAA için tüketilen kuru madde cinsinden yem miktarındaki azalması sebepleriyle işletmenin de karlılığının arttığı bildirilmektedir (Tüzemen, 1995; İmik ve ark., 2000; Cevger ve ark., 2003). Araştırma kapsamına alınan işletmelerde bir kg canlı ağırlık artışı için tüketilen kuru madde cinsinden yem miktarı genel ortalaması $10.28 \pm 0.40 \mathrm{~kg}$ bulunmuştur. I. ve II. grup işletmelerde bu değer genel ortalamaya yakın olduğu görülmüştür. $\mathrm{Bu}$ değerler bazı çalışmalardan (Sakarya ve Günlü, 1996; İmik ve ark., 2000; Çiçek, 2002; Cevger ve ark., 2003; Aydın ve Sakarya, 2012; Can, 2015) yüksek olduğu tespit edilmiştir.

İşletme karlıı̆ını doğrudan etkileyebilecek bir başka teknik özellik olan karkas randımanı sırasıyla, işletmeler genel ortalaması \%53.71; I. grup işletmelerde $\% 53.17$; II. grup işletmelerde $\% 56.86$ olduğu görülmüştür. I. grup işletmelerde bu değer genel ortalama ile benzer iken II. grup işletmelerde ise genel ortalamadan yüksek çıkmıştır. Genel ortalama İmik ve ark. (2000), Gözener ve Sayılı'nın (2015) çalışmalarına benzer; Koç ve Akman (2003), Aydın ve Sakarya'nın (2012) bulduğu değerden ise düşüktür.

Araştırma kapsamındaki işletmelerde maliyeti oluşturan masraf unsurları arasında besilik materyal maliyeti ilk sırayı almaktadır. Genel ortalama \%49.22 olarak bulunmuş, I. ve II. grup işletmelerin ortalaması bu genel ortalamaya yakındır. Bu değerler Çiçek (2002) ve Can (2015)'ın yaptığı çalışmadan düşük, bazı çalışmaların (İmik ve ark., 2000; Yücel, 2007; Uğurtaş, 2008; Aydın ve Sakarya, 2012; Çelik ve Sarı̈zkan, 2014; Malole ve ark., 2014; Gözener ve Sayılı, 2015) bildirdiği değerlerden yüksektir. Diğer çalışmalardan yüksek olmasının nedeni, işletme verilerinin alındığı tarihte Türkiye kırmızı et piyasasında yaşanan fiyat dalgalanmaları, artışları ve ithalat kararlarının canlı hayvan fiyatlarında meydana getirdiği artışlar olabilir.

Masraf unsurları içerisinde ikinci en büyük pay \%32.98'lik genel ortalama ile yem masraflarına aittir. I. ve II. grup işletmelerin ortalaması bu genel ortalamaya yakındır. Bu değerler bazı çalışmalardaki (İmik ve ark 2000; Çiçek, 2002; Aydın ve Sakarya 2012; Can, 2015) değerlerden yüksektir. Bu durumun nede- ni olarak incelenen işletmeler yem teminini kendi üretiminden çok yemi satın alarak sağlaması ve yem fiyatlarındaki (özellikle kesif yem) son dönemdeki dalgalanmalar gösterilebilir. Yine bulunan bu değerler bazı çalışmalardan (Uğurtaş, 2008; Malole ve ark., 2014) düşük iken bazı çalışmalara (Çelik ve Sarıözkan, 2014; Yücel, 2007) ise yakındır. İşletmelerin optimum sayıda besi hayvanını besiye almaları, silaj yem kullanımı ve yem üretimini kendilerinin yapması ile birim maliyetleri azaltmaları mümkün olabilir.

Üretim masrafları içerisinde işçilik masrafları üçüncü sıradadır. İşletmeler genel ortalaması \%8.67 olarak bulunmuştur. I. grup işletmelerdeki bu değer genel ortalamaya benzer iken II. grup işletmelerde ise bu değer genel ortalamadan düşük çıkmıştır. Bunun nedeni olarak II. grup işletmeler daha modern ve teknoloji kullanımı ile besicilik yapmaları gösterilebilir. Bu durum II. grup işletmelerde işgücünün daha verimli kullanıldığını gösterir. İşçiliğin işletmeler ortalaması Aydın ve Sakarya (2012), Çelik ve Sarı̈zkan (2017)'ın bulduğu değerlerden düşük, bazı çalışmalardaki (İmik ve ark., 2000, Çiçek, 2002, Yücel, 2007, Uğurtaş, 2008, Malole ve ark., 2014, Can, 2015) değerlerden ise yüksektir. Bu durumun nedeni olarak aile iş gücünün hesaplanmasındaki metot farklılığı ve yıllar arasındaki iş gücü maliyetlerindeki değişmelerden kaynaklandığı söylenebilir.

Aydın ve Sakarya (2012) yaptıkları çalışmada bir kg karkas, bir kg CAA, bir kg CA maliyetini sırasıyla 12.29 TL (8.09\$), 5.84 TL (3.84\$), 6.99 TL (4.60\$) olarak bulmuşlardır. Köknaroğlu ve ark. (2006)'ın yaptıkları çalışmada bu değerler; $7.64 \mathrm{TL}$ (5.64\$), 4.73 TL (3.49\$) ve 4.35 TL (3.21\$) olarak çıkmıştır. Gözener ve Sayılı 2015 yılında yaptıkları çalışmada yerli, melez ve kültür ırkında sırasıyla bir kg CA maliyeti, $8.23 \mathrm{TL}(4.44 \$), 7.02 \mathrm{TL}(3.79 \$)$ ve $5.47 \mathrm{TL}$ (2.95\$); bir kg CA artış maliyeti, 4.26 TL (2.30\$) ile en yüksek düzeyde yerli ırk, 3.15 TL (1.70\$) ile de en düşük düzeyde kültür ırkı hayvanlara ait olduğunu bildirmişlerdir.

İşletmelerin karlılık durumları değerlendirildiğinde, II. grup işletmelerin daha bilinçli, daha modern ve teknoloji kullanımı ile besicilik yapmaları ya da birinci öncelikli yaptıkları işin besicilik olması nedeniyle daha karlı oldukları söylenebilinir.

İşletmelere ait rantabilite rasyoları ile çıktı-girdi oranları değerlendirildiğinde işletmelerin cari faiz oranının altında ya da cari faiz oranına çok yakın bir kar elde ettikleri belirlenmiştir. Bu şartlar altında sığır besiciliğinin çok karlı olmadığı, sermayenin alternatif maliyeti göz önüne alındığında alternatif maliyetin altında bir gelir elde edildiğini söylemek mümkündür.

Yapılan sosyo-ekonomik incelemeler neticesinde, I. grup işletme sahiplerinin \%50'sinin ilkokul mezunu II. grup işletme sahiplerinin ise \%40'ının lise ve üniversi- 
te mezunu olduğu; yani iki grup arasında eğitim düzeyi yönünden farklılık olduğu tespit edilmiştir. Yapılan bazı araştırmalar sonucunda işletme sahiplerinin eğitim düzeyi yükseldikçe işletmelerin; kültür ırkı hayvan temini, besi süresi, besi şekli, hayvanların günlük canlı ağırlık artışı ve işletme net karı gibi konularda daha etkili ve verimli olduğu tespit edilmiştir (Eren, 2006; Köknaroğlu ve ark., 2007).

İşletme sahiplerinin büyük bir kısmı sığır besiciliğini ek iş olarak yapmaktadırlar. Yapılan bir çalışmada, işletme sahiplerinin besicilik dışında ek iş yapmalarının bu iş koluna yeterli emek ve zaman harcamalarına engel olduğu için elde edilen net karın olumsuz yönde etkilendiğini bildirmişlerdir (Çelik ve Sarıözkan, 2017). Aynı çalışmadaki işletme sahiplerinin az bir kısmı ise karlı bir iş olduğu için sığır besiciliği yaptıklarını bildirmişlerdir.

İşletme sahipleri ile yapılan anketler neticesinde sığır besiciliği ile ilgili tespit edilen bazı sorunlar ve bunların çözümüne ilişkin öneriler şöyledir:

Kasaplık hayvan tedarikinde ve pazarlanmasında aracıların piyasayı bozması ve piyasadaki oligopsonik yapı üreticiler aleyhine işlemekte ve istikrarsızlığa neden olmaktadır. Bu sorun gerek girdi tedarikinde gerekse besi sonu hayvanların/kesime sevk edilmesinde üretici maliyetlerinden bağımsız tek yanlı bir fiyat oluşmasına neden olmaktadır. Bu durum üreticilerin kazancının düşmesine, tüketicinin ise daha pahalıya ürün almasına yol açmaktadır. Üretici ve tüketici refahını olumsuz etkilemektedir. Bu anlamda hem aracı sayısının hem de aracı marjlarını azaltıcı tedbirler alınması gerekmektedir. Kasaplık hayvan ve et ticareti konusunda ülke içerisinde üreticiden tüketiciye kadar olan zincirde hem üreticiyi hem de tüketiciyi koruyacak önlemler alınmalıdır. Bu önlemler hayvansal ürünlerde üretim ve verimliliğin artırılması, üretim maliyetlerinin düşürülmesi ve pazarlama zincirinin kısaltılarak verimliliğin yükseltilmesi, üretimde kalite ve sağlık koşullarını iyileştirici, fiyat ve pazar mekanizmasını geliştirici tedbirler olabilir.

Sığır besiciliğinde en önemli girdi unsurlarından olan yem giderlerinin yüksek oluşu da üreticilerin karlıığını etkileyen önemli bir faktördür. Besiciler için yem maliyetinin önemli ölçüde azaltılması büyük önem arz etmektedir. Bu bakımdan yem bitkisi üretimine yönelik desteklerin artarak devam etmesi, mera ıslah çaış̧malarına hız verilmesi ve meraların korunması üzerine birtakım tedbirlerin alınmasının besiciler için faydalı olabileceği düşünülmektedir.

Süt sığırcılığının dönemsel olarak karlı olmaması nedeniyle yaşanan sorunlar ve buna bağlı zaman zaman ortaya çıkan damızlık hayvan kesimleri de besicilik için önemli sorunlardan biridir. Süt ve kırmızı et alt sektörleri birbirinin rakibi veya alternatifi değil bütünleyicisidir. Süt fiyatlarındaki dalgalanmaların ve inek sütü ile sığır eti üretiminin birbirlerini olumsuz etkilemesinin önüne geçecek yeni stratejilerin ortaya konulması gerekmektedir. Ayrıca süt sığırcılığının çıktısı olan erkek buzağılar sığır besiciliğinin girdisi olması nedeniyle buzağı ölümlerinin azaltılması için gerekli tedbirler kısmen alınmış olsa da bu tedbirlerin artırılması ve geliştirilmesi üzerine çalışmalar yapılmalıdır.

Bulaşıcı hayvan hastalıkları da sığır besiciliğinde karlılığı etkilemektedir. Hayvan hastalıkları ile mücadele ve eradikasyon çalışmalarında uygulanan yöntemler ve stratejiler geliştirilmelidir. Ülke içi ve dışı hayvan hareketleri denetimleri daha yeterli ve etkili hale getirilmelidir. Bu konuda özellikle celeplere ciddi yaptırımlar uygulanmalıdır. Çünkü hastalık çıkışı yapılan bölgelerden veteriner sağlık raporu almadan hayvan satışı yaparak bulaşıcı hayvan hastalıklarının yayılmasına sebebiyet vermektedirler. Bulaşıcı hayvan hastalıklarının mücadelesinde uygulanan aşılama kampanyaları ile üreticilerin eğitim, seminer gibi faaliyetlerle bilinçlenmeleri sağlanmalıdır.

Yapılan çalışmada hayvancılık desteklemeleri için üreticiler her ne kadar olumsuz bir görüş bildirmeseler de aslında desteklemeler tam anlamıla istenilen amaca hizmet etmemektedir. Hayvancılık desteklemeleri üretimi teşvikten daha çok bulaşıcı hayvan hastalıkların aşılarının yaptırıması, hayvan hareketlerinin kontrolü gibi bazı uygulamalar için aracı olarak kullanılmaktadır. Desteklemelerin üreticilerin taleplerini ve ihtiyaçlarını karşılayacak düzeyde, üretimi daha çok teşvik edici olmasına özen gösterilerek geliştirme çalışmaları yapılmalıdır. Özellikle desteklemeler ve bir takım politikalar üretim sürecinde üreticilerin aleyhine işleyecek bir hale dönüştürülmemeli ve besi başlangıcında mevcut şartlara göre kendini hazırlayan üreticilerin ekonomik faaliyetini olumsuz etkileyecek girişimlerden uzak durulmalıdır.

Kasaplık hayvan ve et ithalatı kırmızı et üretiminde istenmeyen yanları ile sıkça tartışılmaktadır. Yapılan ithalat ve uygulama süresindeki belirsizlik, fiyatların düşeceği tedirginliğini oluşturarak besicilerin ellerindeki kesim olgunluğuna ulaşmamış hayvanlarını kesime göndermelerine neden olabilmektedir. Hatta bazı üreticiler işletmelerindeki bütün hayvanlarını elden çıkararak sektörü bırakma kararı alabilmektedir. İthalat başlangıçta et arzının artmasını ve et fiyatlarının düşmesini sağlayabilmektedir. Ancak orta ve uzun vadede kesim olgunluğuna ulaşmamış hayvanların kesilmesi, bazı üreticilerin sektörü bırakması, fiyat istikrarsızlıklarının oluşması, bulaşıcı hastalık tehlikesi gibi ciddi sorunlara yol açmakta ve kırmızı et üretiminde tamamen dış bağımlılığa neden olabilmektedir (Aydın ve ark., 2011a; Sakarya ve Aydın, 2011; Aydın ve ark., 2011b). Kasaplık hayvan ve et ithalatın önüne geçilmesi ya da kademeli olarak ithalatın sonlandırılması için ülke içinde kasaplık hayvan üretimi ve canlı hayvan stokunun artırılarak, kırmızı et piya- 
sasında arz talep dengesi sağlanarak gerçekleştirilebilir (Kırmızı Et Sektörü Komisyonu, 2011). İthalat bu amacın gerçekleştirilmesinin bir aracı olarak görülmelidir.

Sonuç olarak, yerli orijinli ve ithal besi materyali kullanan işletmelerin maliyeti oluşturan masraf unsurların$\mathrm{da}$, bir $\mathrm{kg} \mathrm{CA}$ maliyeti ve bir $\mathrm{kg}$ karkas maliyetinde önemli bir farklılık tespit edilememiştir. Bu iki grup işletmenin gelirleri ve karları arasında az miktar farklılık bulunsa da; bu durum ithal besi materyali ile besicilik yapan işletmeler diğer gruba göre daha bilinçli, teknolojiyi kullanabilen, daha modern işletmecilik anlayışında olmalarından kaynaklanabilir. Kasaplık hayvan ve et ithalatı, sektördeki sorunların çözümü için her ne kadar önerilmese de alınan kararlarla bazı dönemlerde gerçekleştirilmektedir. Bu çalışmanın sonuçları ithalat konusunda karar vericilere ve sektördeki üreticilere yol gösterici olması bakımından önemlidir.

\section{Teşekkür}

Çalışmanın gerçekleştirilmesindeki katkılarından dolayı Dr. Öğretim Üyesi M. Bahadır Çevrimli'ye teşekkürlerimizi sunarız.

\section{Kaynaklar}

Akbulut Ö, Tüzemen N, Aydın R. Esmer ve SiyahAlaca tosunların açık ahırlarda besi performansı ve karkas özellikleri. Tübitak Doğa-Vet Hay Derg 1995; 19(1): 409-16.

Altuntaş M, Arpacık R. Farklı yaslarda besiye alınan Simental tosunların besi performansı ve optimum kesim ağırıkları. Lalahan Hay Araşt Enst Derg 2004; 44(1): 7-16.

Aydın E. Kars ve Erzurum illeri sığır besi işletmelerinin ekonomik analizi, Doktora tezi, Ankara Üniv Sağ Bil Ens, Ankara 2011; ss. 72-82.

Aydın E, Can MF, Aral Y, Cevger Y, Sakarya E. Türkiye'de canlı hayvan ve kırmızı et ithalatı kararlarının sığır besicileri üzerine etkileri. $A B$ Uyum Sürecinde Türkiye Hayvancılık Kongresi, 20-22 Ekim 2011a; 733-44, Ankara-Türkiye.

Aydın E, Can MF, Aral Y, Cevger Y, Sakarya E, İşbilir S. Türkiye'de son 25 yılda kırmızı et fiyatlarındaki değişimler ve ithalat kararlarının etkilerinin analizi. Vet Hekim Der Derg 2011b; 82(1): 3-13.

Aydın E, Sakarya E. Kars ve Erzurum illeri entansif sığır besi işletmelerinin ekonomik analizi. Kafkas Univ Vet Fak Derg 2012; 18(6): 997-1005.

Can MF. Ankara ili merkez ilçelerindeki sığır besi işletmelerinin ekonomik analizi. Eurasian J Vet Sci 2015; 31(2): 87-94.
Cevger Y, Güler H, Sarı̈̈zkan S, Çiçek H. The effect of initial live weight on technical and economic performance in cattle fattening. Turk $\mathrm{J}$ Vet Anim Sci 2003; 27(5), 1167-71.

Çelik C, Sarı̈̈zkan S. Kırşehir ili merkez ilçede sığır besiciliği yapan işletmelerin ekonomik analizi. Harran Üniv Vet Fak Derg 2017; 6(1): 38-45.

Çiçek H. Afyon ili sığır besiciliği işletmelerinde karlılık ve verimlilik analizleri. Lalahan Hay Araşt Enst Derg 2003; 43(2):1-13.

Eren E. Kahramanmaraş ili Göksun ilçesinde sığır besiciliği yapan işletmelerin yapısı ve sorunları, Yüksek lisans tezi, Kahramanmaraş Sütçü İmam Üniv Fen Bil Enst, Kahramanmaraş 2006; s. 27

Esfahani MS, Dougherty ER. Effect of separate sampling on classification accuracy. Bioinformatics 2014; 30(2):242-50.

Gözener B, Sayılı M. Tokat ili Turhal ilçesinde sığır besiciliğinde üretim maliyeti ve canlı ağırlık artışına etki eden faktörler. Tar Bil Derg 2015; 21(2) 28899.

Hazneci K. Amasya ili Suluova ilçesinde sığır besiciliği yapan işletmelerin etkinlik analizi, Yüksek lisans tezi, On dokuz Mayıs Üniv Fen Bil Enst, Samsun 2007; s. 84

İmik H, Günlü A, Tekerli M, Koçak S. Afyon ilinde yapılan sığır besiciliğinin ekonomik analizi ve karlı bir besicilik için alınması gerekli önlemler. Lalahan Hay Araşt Enst Derg 2000; 40(2): 1-15.

Kırmızı Et Sektörü Komisyonu. Kırmızı et sektörü komisyonu çalışma sonuç raporu, $A B$ Uyum Sürecinde Türkiye Hayvancılık Kongresi. 20-22 Ekim 2011; Ankara-Türkiye.

Koç A, Akman N. Farklı ağırlıklarda besiye alınan ithal edilmiş siyah-alaca tosunların besi gücü ve karkas özellikleri. Hayvansal Üretim 2003; 44(1): 26 -36 .

Köknaroğlu H, Demircan V, Yılmaz H, Dernek Z. Besi sığırcılığı üretim faaliyetinde üreticilerin eğitim düzeylerinin besi performansı ve karlılığa etkisi. V. Ulusal Zootekni Kongresi. Eylül, 5-8, 2007; VanTürkiye.

Köknaroğlu H, Yılmaz H, Demircan V. Afyon ili besi sığırcılığı işletmelerinde kesif yem oranının besi performansı karlılığa etkisi. Süleyman Demirel Üniv. Ziraat Fak Derg 2006; 1(1): 41-51.

Malole JL, Kadigi RJM, Sangeda AZ. Costs and benefits of beef cattle fattening schemes in some selected areas of north west Tanzania. IJAS 2014; 4(4): 699-706. 
Muižniece I, Kairiša D. Different beef breed cattle fattening results analysis. Agricultural Sciences (Crop Sciences, Animal Sciences) 2016; (1): 27-62.

Özlütürk $A$, Esenbuğa $N$, Yanar $M$, Ünlü $N$, Macit $M$, Kopuzlu S. The effect of duration of finishing period on the performance, slaughter, carcass, and beef quality characteristics of Eastern Anatolian Red Bulls. Turk J Vet Anim Sci 2008; 32(6): 441-8.

Sakarya E, Günlü A. Limuzin x Jersey (F1) melezi ve Holştayn ırkı tosunlarda optimal besi süresinin tespiti üzerine bir araştırma. Ankara Üniv Vet Fak Derg 1996; 43(1): 113-20.

Sakarya E, Aydın E. Türkiye'nin canlı hayvan ve sığır eti ithalatı. ATB Yayın Organı, Borsa Vizyon Dergisi 2011.

Syrůček J, Kvapilík J, Bartoň L, Vacek M, Stádník L. Economic efficiency of bull fattening operations in the Czech Republic. Acta Unive Agric Silvic Mendel Brun, 2017; 65(2): 527-36.

T.C. Gıda Tarım ve Hayvancılık Bakanlığı (GTHB) HAYGEM. Kırmızı Et Stratejisi. Ankara, 2015; 5564.

Topcu Y. Erzurum ili sığır besiciliği işletmelerinde girdi kullanımı ve üretim maliyeti üzerine bir araştırma, Atatürk Üniv Ziraat Fak Derg 2004; 35(1-2): 65 -73 .

Tüzemen N. Farklı yaş ve farklı barındırma sistemlerin-de esmer ırkı tosunların besi performansları. Atatürk Üniv Ziraat Fak Derg 1995; 26(1): 9-20.

Uğurtaş FT. Konya ili Beyşehir ilçesi Doğanbey beldesinde sığır besiciliğine yer veren tarım işletmelerinin ekonomik analizi, Yüksek lisans tezi, Atatürk Üniv Fen Bil Enst, Erzurum 2008; ss. 58-61.

Yücel S. Ankara ili tarım işletmelerinde sığır besiciliği üretim faaliyetlerinin teknik ve mali analizi, Yüksek lisans tezi, Ankara Üniv Fen Bil Enst, Ankara 2007; 24-34. 
